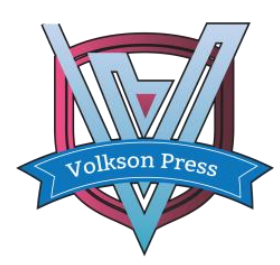

\title{
PREPARATION AND PERFORMANCE OF MICROORGANISM MINERALIZED STEEL SLAG CEMENTING MATERIAL
}

\author{
Haihe Yi, Chun xiang Qian \\ College of Materials Science and Engineering, Research Institute of Green Construction Materials, Southeast University, Nanjing 211189, PR China \\ This is an open access article distributed under the Creative Commons Attribution License, which permits unrestricted use, distribution, and reproduction in \\ any medium, provided the original work is properly cited
}

\section{ARTICLE DETAILS}

\section{Article History:}

Received 02 october 2017 Accepted 06 october 2017 Available online 11 november 2017

Keywords:

Microorganism, carbonate, mineralization

\section{ABSTRACT}

In this paper, the steel slag-lime system was used to prepare steel slag products under the enzymatic action of microorganisms. The results showed that, after $3 \mathrm{~h}$ carbonization, the compressive strength increased from 32.8MPa to $49.5 \mathrm{MPa}$, the strength of steel slag products was improved obviously. By CT and other analytical tools, the mineralization depth of microorganism is obviously deepened, and the pore structure is optimized. The results show that the amount calcium carbonate significantly improved, the calcium carbonate filling in the pores around, the pore structure has been optimized, the strength has been improved. In addition, microorganisms have the role of loading and catalytic, on one hand, it can be a steady stream of carbon dioxide which transport it into the brick to happen sequestration, on the other hand, the secretion of the enzyme can significantly accelerate the hydration reaction rate of carbon dioxide, which will form more and more $\mathrm{CO}_{3}{ }^{2-}$ inside the brick, so a higher probability of $\mathrm{Ca}^{2}$ + and $\mathrm{CO}_{3}{ }^{2-}$ combining to generate $\mathrm{CaCO}_{3}$.

\section{Introduction}

The steel industry is the basic industry of the national economy. In the situation of the rapid economic development of the country, the steel industry also presents the trend of leapfrog development [1].Steel slag is in the process of iron and steel production by slagging reactants, erosion loose materials, smelting furnace and furnace material, metal furnace charge into the impurities and specially for adjust the properties of steel slag and join the slagging materials composed of solid slag, is a by-product of the production process of steel, the number of general for crude steel output by $12 \%$ to $20 \%$ [2-4].The yield of steel slag is closely related to the equipment level and metallurgical technology, and the process of making steel less slag or even slag is widely used in developed industrial countries. However, due to the backward production technology in China, the quality of raw materials is poor, the steel slag of steel production is more, and the production of steel slag of 1-ton steel [5]. In recent years, China's steel output has reached 800 million tons, producing more than 120 million tons of steel slag annually, and still growing by more than 30 million tons per year. If there is no reasonable way to make comprehensive use of these steel slag, there will inevitably be a lot of harm to the social environment, such as occupying the land, polluting the air and wasting resources [6].

The activity main mineral composition of steel slag is C2S, C3S, C4AF and RO, and activity main mineral composition are very similar compared to the cement gel activity, the activity of steel slag is low, studies have shown that steel slag in $48 \mathrm{~h}$ is only the total hydration heat of cement of $10.5 \%$, but this kind of hydraulic steel slag stimulated amplification can be treated with a certain way [7]. In recent years, it has been widely used in the field of traditional building materials: production of steel slag cement, preparation of steel slag concrete, and backfilling and reinforcement of foundation $[8,9]$. According, to the research, the slurry can stimulate the potential activity of steel slag, and the slurry is also the ideal material for fixing $\mathrm{CO}_{2}$ and preparing slag products [10]. With slaked lime as alkali excitation agent, therefore, use of industrial waste steel slag fine powder, in the role of microbial enzymatic, prepared microbial products, efficient solid carbon steel slag to study the mechanical properties and microscopic mechanism of carbon sequestration.

In this experiment, a bacterium that can produce carbonic anhydrase was used to produce steel slag materials, and the rate of microbiological mineralization was significantly increased compared with the normal carbonization process. Class basophilic bacteria can capture $\mathrm{CO}_{2}$ in the air, its special enzyme characteristics can effectively improve the hydration reaction of $\mathrm{CO}_{2}$, promote the shift towards $\mathrm{HCO}^{-}$and $\mathrm{CO}_{2}$ in the alkaline solution environment, $\mathrm{HCO}_{3}{ }^{-}$and $\mathrm{OH}$ - quick response to generate $\mathrm{CO}_{3}{ }^{2}$, chelating environment constantly $\mathrm{Ca}^{2+}$ calcium carbonate precipitation [11]. Unlike the more commonly used bacteria, this type of bacteria is used as an inorganic carbon source for mineralization of $\mathrm{CO}_{2}$ in the air [12]. The carbon dioxide in the air is everywhere and continuously, and the efficiency of inorganic carbon source is improved, and the efficiency of the bacterial enzyme solution is improved [13]. In the $\mathrm{H}_{2} \mathrm{O}-\mathrm{CO}_{2}-\mathrm{Ca}^{2+}$ system, eosinophilic microorganisms in cell surface induced deposition of $\mathrm{CaCO}_{3}$ biochemical reaction can be expressed by formula (1-1) to formula (1-4).

$$
\begin{aligned}
& \mathrm{CO}_{2}+\mathrm{H}_{2} \mathrm{O} \leftrightarrow \mathrm{HCO}_{3}^{-}+\mathrm{H}^{+} \\
& \mathrm{HCO}_{3}^{-}+\mathrm{OH}^{-} \rightarrow \mathrm{CO}_{3}^{2-}+\mathrm{H}_{2} \mathrm{O} \\
& \mathrm{Ca}^{2+}+\mathrm{Cell} \rightarrow \mathrm{Cell}-\mathrm{Ca}^{2+} \\
& \text { Cell }-\mathrm{Ca}^{2+}+\mathrm{CO}_{3}^{2-} \rightarrow \text { Cell }-\mathrm{CaCO}_{3}
\end{aligned}
$$

\section{MATERIAL AND METHODS}

\subsection{Bacterial culture}

A species of bacteria that produces carbonic anhydrase is chosen. Strain fermentation medium are shown in table 1 , regulate the fermentation culture medium $\mathrm{pH}=7$, placed in a triangle in the bottle, at $121{ }^{\circ} \mathrm{C}$ high temperature sterilization $25 \mathrm{~min}$. Remove the sterilized triangle bottle in

\begin{tabular}{|c|c|c|c|c|c|c|}
\hline Sucrose & $\mathrm{NaHPO}_{4} .12 \mathrm{H}_{2} \mathrm{O}$ & $\mathrm{MgSO}_{4}$ & $\mathrm{CaCO}_{3}$ & KCL & $\left(\mathrm{NH}_{4}\right)_{2} \mathrm{SO}_{4}$ & Yeast extract \\
\hline 10.00 & 2.50 & 0.25 & 1.00 & 1.00 & 0.50 & 0.20 \\
\hline
\end{tabular}
the oven to dry, to be used. Inoculation of carbonic anhydrase purified strains in the sterile culture medium, culture in $30^{\circ} \mathrm{C}$ oscillation incubator for $24 \mathrm{~h}$, the oscillation frequency of $170 \mathrm{r} / \mathrm{min}$.

\subsection{Raw Material}

Main chemical compositions of the steel slag as shown in table 2, the main composition of steel slag and cement clinker are similar, its main chemical composition of calcium oxide, silicon oxide, aluminum oxide and magnesium oxide, and partial oxidation, such as iron oxide. 
Table 2: Chemical composition of steel slag/w \%

\begin{tabular}{lccccccc}
\hline Component & $\mathbf{C a O}$ & $\mathbf{S i O}_{2}$ & $\mathbf{A l ~ O}_{2}$ & $\mathbf{M g O}$ & $\underset{2}{\mathbf{F e ~ O}_{3}}$ & $\underset{2}{\mathbf{P O}_{5}}$ & $\mathbf{S O}_{3}$ \\
\hline mass/\% & 43.7 & 13.1 & 9.1 & 5.8 & 17 & 7.2 & 0.6 \\
\hline
\end{tabular}

\subsection{Preparation of microorganism mineralized steel slag cementing} materials

Strain after $24 \mathrm{~h}$, under $5{ }^{\circ} \mathrm{C}, 9000 \mathrm{r} / \mathrm{min}$ speed centrifugal $10 \mathrm{~min}$, remove the supernatant fluid. After the addition of ionized water washing, the above process was repeated, and the concentration of the high strain cell was $2^{*} 10^{9} / \mathrm{mL}$. The experiment was based on the micro-powder of steel slag and the slurry, the standard sand was the aggregate, and the specific distribution was shown in table 3 . The specimen obtained at room temperature $\left(25+2{ }^{\circ} \mathrm{C}\right)$ environment static maintenance for $24 \mathrm{~h}$, A batch of samples in the carbonization pressure kettle, carbide carbide parameters as follows: temperature $25^{\circ} \mathrm{C}$, relative humidity $60 \%, \mathrm{CO}_{2}$ gas pressure is $0.30 \mathrm{Mpa}$, carbonization time $3 \mathrm{~h}$. Another group of let stand not carbide, carbide parameters: temperature $25{ }^{\circ} \mathrm{C}$, relative humidity $60 \%$, atmospheric pressure stand for $3 \mathrm{~h}$.

Table 3: Mix proportions of Steel slag products/g

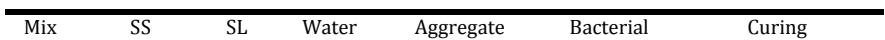

\begin{tabular}{lllllll}
\hline A1 & 525 & 105 & 315 & 1250 & 0 & standard \\
A2 & 525 & 105 & 315 & 1250 & 3.15 & standard \\
A3 & 525 & 105 & 315 & 1250 & 6.3 & standard \\
A4 & 525 & 105 & 315 & 1250 & 9.45 & standard \\
B1 & 525 & 105 & 315 & 1250 & 0 & carbonation \\
B2 & 525 & 105 & 315 & 1250 & 3.15 & carbonation \\
B3 & 525 & 105 & 315 & 1250 & 6.3 & carbonation \\
B4 & 525 & 105 & 315 & 1250 & 9.45 & carbonation \\
\hline
\end{tabular}

\section{RESULTS AND DISCUSSION}

\subsection{Strength}

Figure 1 shows the compressive strength of carbonized steel slag brick and micro-organism mineralized brick under two kinds of curing conditions. As can be seen from the figure, the compressive resistance of steel slag bricks increases with the increase of microbial addition in both natural and carbonized maintenance. Under natural curing conditions, the compressive strength of the non-microbial group was3.2 $\mathrm{MPa}$, and the strength of the microorganism was $9.15 \mathrm{ml}$, and the strength was $7.9 \mathrm{MPa}$. When the pressure of carbon dioxide conservation was $0.3 \mathrm{MPa}$, the compressive strength of the non-microbial group was $32.8 \mathrm{MPa}$. The strength of the microorganism was up to $49.5 \mathrm{MPa}$ and the strength increased by $50 \%$ when the microorganism added $9.15 \mathrm{ml}$.

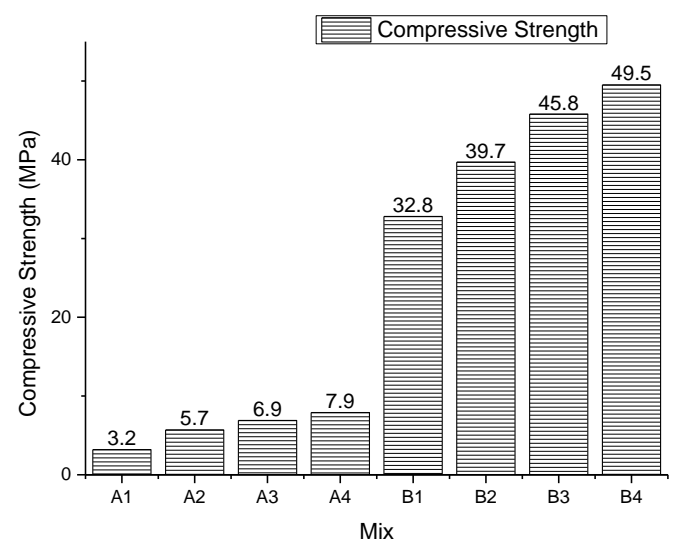

Figure 1: Strength of steel slag

\subsection{Mineralization depth}

Sample of uncarbonized control group, sample of carbonized control group and microorganism accelerated carbonization test samples. The staining of the sample cross-section shows that the whole cross-section of the uncarbonized control group is red, indicating that the $\mathrm{Ca}(\mathrm{OH})_{2}$ in the whole cross section is not completely reacted and the carbonization is incomplete. Control group are part of the red sample center, carbide edges show colorless, edges that section completely, carbide generated $\mathrm{CaCO}_{3}$, so colorless, but the incomplete carbonization, cross section and the remnants of the $\mathrm{Ca}(\mathrm{OH})_{2}$, which is red. The whole section of the sample of microorganism accelerated carbonation is colorless, indicating that the carbon dioxide has been completely diffused into the inner and $\mathrm{Ca}(\mathrm{OH})_{2}$ carbonization completely, which is converted into CaC03.The phenomenon of phenolphthalein staining showed that the microorganism could accelerate the carbonization reaction significantly and increase the carbonization depth, so that more $\mathrm{Ca}(\mathrm{OH})_{2}$ carbonation was converted into $\mathrm{CaCO}_{3}$.

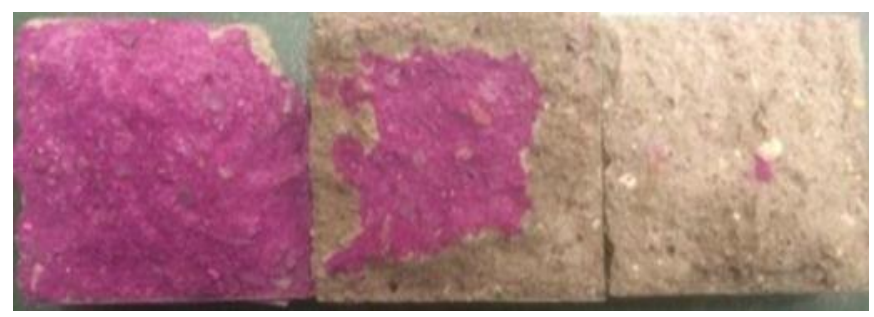

Figure 2: Mineralization depth of samples

\subsection{Pore structure Analysis}

Three-dimensional CT scan, different colors represent different aperture size and its distribution, can be seen from the figure 3 . The control sample, microorganism accelerating carbide carbide group samples are marginal porosity is small, the farther the internal porosity is larger. The pore distribution of the sample of microorganism accelerated carbonization group was the most uniform, and the margin and internal porosity were small. The pore distribution, edge and internal pore difference of the sample of the carbonization control group were poor. This is also a good illustration of the reasons for the more uniform densification of the sample of microorganism accelerated carbonization group than the carbonization control group.
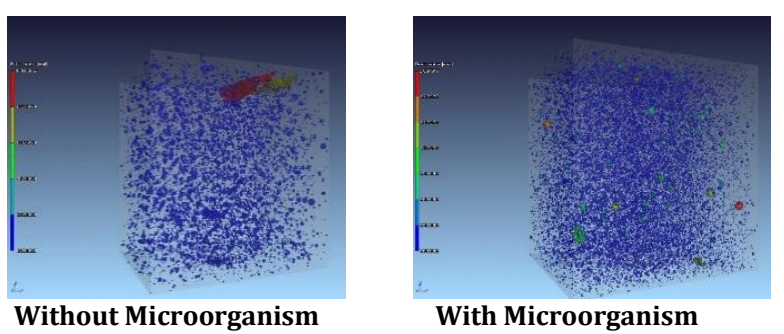

With Microorganism

\section{CONCLUSION}

Figure 3: Three-dimensional CT scan of steel slag

The production of calcium carbonate in the slag-lime system is significantly increased, and the pore structure is optimized, and the strength is improved. Carbonation reaction intensity enhancement effect of steel slag slaked lime gel system, carbide generated in the process of calcium carbonate on the body of filling effect, is analyzed the main cause of pore structure optimization and increase strength. The microorganism is added, and the mineralization reaction is enhanced to further fill the pore of the matrix, and the strength is obviously improved. Microorganism to slide and catalytic role, on the one hand, can be a steady stream of $\mathrm{CO}_{2}$ transport to the carbonation reaction in brick, on the other hand can significantly accelerate the secretion of enzyme carbon dioxide hydrate reaction speed, so as to form more $\mathrm{CO}_{3}{ }^{2}$-inside the brick, $\mathrm{Ca}^{2}$ have a higher chance and generate $\mathrm{CaCO}_{3}$ with $\mathrm{CO}_{3}{ }^{2}$ - combined.

\section{ACKNOWLEDGEMENTS}

This study was funded by science and technology department of Jiangsu provincial (BE2015678). The authors declare that they have no conflict of interest.

\section{REFERENCE}

[1] Manso, J.M., Losáñez, M., Polanco, J.A., González, J.J. 2005. Ladle furnace slag in construction. Journal of Materials in Civil Engineering, 17 (5), $513-$ 8.

[2] Setién, J., Hernández, D., González, J.J. 2009. Characteristics of ladle furnace basic slag for use as a construction material. Construction and 
Building Materials, 23 (5),1788-1794.

[3] Shi, C. 2002. Characteristics and cementitious properties of ladle slag fines from steel production. Cement and Concrete Research, 32 (2), 45962 .

[4] Adolfsson, D., Robinson, R., Engstrom, F., Bjorkman, B. 2011. Influence of mineralogy on the hydraulic properties of ladle slag. Cement and Concrete Research, 41 (8), 865-71.

[5] Shi, C., Hu, S. 2003. Cementitious properties of ladle slag fines under autoclave curing conditions. Cement Concrete Research, 33 (11), 18511856.

[6] Papayianni, I., Anastasiou, E. 2012. Effect of granulometry on cementitious properties of ladle furnace slag. Cement Concrete Composites, 34 (3), 400-407.

[7] Murri, A., Rickard, W.D.A., Bignozzi, M.C., Riessen, V. A. 2013. High temperature behavior of ambient cured alkali-activated materials based on ladle slag. Cement Concrete Research, 43, 51-61.
[8] Isoo, T., Takahashi, T., Okamoto, N., Fukuhara, M. 2000. Development of large steelmaking slag blocks using a new carbonation process. Advances in Cement Research, 12 (3), 97-101.

[9] Johnson, D.C., MacLeod, C.L., Carey, P.J., Hills, C.D. 2003. Solidification of stainless steel slag by accelerated carbonation. Environment Technology, 24 (6), 671-8.

[10] Monkman, S., Shao, Y. 2006. Assessing the Carbonation Behavior of Cementitious Materials. Journal of Materials in Civil Engineering, 18 (6), 768-76.

[11] Cao, W., Yang, Q. 2015. Properties of a Carbonated Steel Slag-Slaked Lime Mixture. Journal of Materials in Civil Engineering, 27 (1), 0401-4115.

[12] Dreybrodt, Eisenlohr, L. 1998. Precipitation kinetics of calcite in the system $\mathrm{CaCO} 3-\mathrm{H} 2 \mathrm{O}-\mathrm{CO} 2$ : the convers ionto $\mathrm{CO} 2$ by the slow process $\mathrm{H}++\mathrm{HCO} 3--\mathrm{CO} 2+\mathrm{H} 2 \mathrm{O}$ as a rate limiting step. Geochimica et Cosmochimica Acta, 61 (18), 3897-3904.

[13] Heck, R.W., Tanhauser. 1994. Catalytic properties of mouse carbonic anhydrase V. The Journal of Biological Chemistry, 269 (40), 24742-24746. 